Abstracta Iranica Abstracta Iranica

Revue bibliographique pour le domaine irano-aryen

Volume 29 | 2008

Comptes rendus des publications de 2006

\title{
" Investiture I. Achaemenid period ». EIr, vol. XIII, fasc. 2, 2005, pp. 180-182, 2 fig.
}

\section{Karin Mosig-Walburg}

\section{(2) OpenEdition}

1 Journals

Édition électronique

URL : http://journals.openedition.org/abstractairanica/25802

DOI : 10.4000/abstractairanica.25802

ISSN : 1961-960X

\section{Éditeur :}

CNRS (UMR 7528 Mondes iraniens et indiens), Éditions de l'IFRI

\section{Édition imprimée}

Date de publication : 15 mai 2008

ISSN : 0240-8910

\section{Référence électronique}

Karin Mosig-Walburg, « «Investiture I. Achaemenid period ». Elr, vol. XIII, fasc. 2, 2005, pp. 180-182, 2 fig. », Abstracta Iranica [En ligne], Volume 29 | 2008, document 69, mis en ligne le 15 septembre 2008, consulté le 26 septembre 2020. URL : http://journals.openedition.org/abstractairanica/25802 ; DOI : https://doi.org/10.4000/abstractairanica.25802

Ce document a été généré automatiquement le 26 septembre 2020.

Tous droits réservés 


\title{
« Investiture I. Achaemenid period ». EIr, vol. XIII, fasc. 2, 2005, pp. 180-182, 2 fig.
}

\author{
Karin Mosig-Walburg
}

1 L'A. a rassemblé toutes les informations disponibles sur l'investiture des rois perses à partir de Cyrus II. La base très restreinte des sources, qui sont pour la plupart d'origine non iranienne, ne permet souvent que des conjectures. Avec raison, les hypothèses suivantes, soutenues par une partie des savants, mais qui se basent sur les informations des sources occidentales, sont refusées : l'idée d'une déesse belliqueuse, identifiée à Anahita, par laquelle le roi aurait été investi, et l'idée que les Achéménides auraient bâti des temples. L'A. souligne le fait que cette dernière hypothèse est en contradiction avec les pratiques religieuses des Perses et que les sources montrent bien la fonction du dieu suprême Ahura Mazda comme le dieu qui procède à l'investiture du roi. Cette investiture des rois achéménides était célébrée à Pasargades.

\section{INDEX}

Thèmes : 3.2.2. Pré-Achéménides et Achéménides

\section{AUTEURS}

KARIN MOSIG-WALBURG

Université de Francfort 